\title{
POPULAÇÃO CARCERÁRIA INDÍGENA E O DIREITO À DIFERENÇA: O CASO DO MUNICÍPIO DE DOURADOS, MS
}

\author{
Rosely Aparecida Stefanes Pacheco, Rafael Clemente Oliveira do Prado \\ e Ezequias Vergilio Kadwéu
}

FOR A RIGHT TO DIFFERENCE: CRIMINAL AND LEGAL SITUATION OF INDIGENOUS PRISONERS IN DOURADOS, MS

\section{RESUMO}

ESTE ARTIGO TEM ENTRE SEUS OBJETIVOS LANÇAR UMA ANÁLISE REFLEXIVA SOBRE A SITUAÇÃO DOS DETENTOS INDÍGENAS NO município de Dourados, Estado de Mato Grosso do Sul. DESTACA-SE QUE O PROBLEMA TEÓRICO SE EMBASA NO FATO DE QUE, APESAR DE EXISTIREM INÚMEROS TEXTOS LEGAIS, PACTOS, PROTOCOLOS, DECLARAÇÕES E AFINS, TANTO DE CARÁTER NACIONAL QUANTO INTERNACIONAL, PARA A PROTEÇÃO DOS DIREITOS DOS POVOS INDÍGENAS, VERIFICAM-SE CONSTANTES VIOLAÇÕES A ESSES DIREITOS QUE FAZEM PARTE DA universalidade dos direitos humanos. Portanto, SURgem QUESTIONAMENTOS: QUAL SERÁ A LACUNA QUE IMPEDE A DEVIDA IMPLEMENTAÇÃO DOS DIREITOS DOS POVOS INDÍGENAS ENTRE A POPULACÃO CARCERÁRIA INDÍGENA NO ESTADO DO Mato Grosso do Sul? Para a construção deste texto RECORREMOS AOS APORTES DE VÁRIAS DISCIPLINAS, TAIS COMO: DIREITO CONSTITUCIONAL, PENAL, INTERNACIONAL E DIREITOS HUMANOS, POR ESTAREM INTIMAMENTE INTERCONECTADOS COM A PROTEÇÃO DOS DIREITOS DOS POVOS INDÍGENAS. O DIREITO AQUI ABORDADO SERÁ POR MEIO DE UMA PERSPECTIVA INTERDISCIPLINAR DIANTE DAS VÁRIAS ÁREAS DO CONHECIMENTO, COM O INTUITO DE QUE SE POSSA AVANÇAR NA COMPREENSÃO DESSA TEMÁTICA, FAZENDO UMA MENÇÃO ESPECIAL À ANTROPOLOGIA JURÍDICA. O MÉTODO ADOTADO FOI O DESCRITIVO-ANALÍTICO, APLICANDO-SE A ANÁLISE DOCUMENTAL E BIBLIOGRÁFICA AO CASO CONCRETO. ALÉM DO QUE NOS VALEMOS DE ESTUDOS DE CASOS, CONFORME NOS PROPÕE A ETNOGRAFIA E A PRÁTICA JURÍDICA LOCAL, QUANDO SE TRATA DE ESTUDAR CULTURAS DIVERSAS.

\section{PALAVRAS-CHAVE}

Diversidade; Povos indígenas; Política carcerária: Direitos humanos, Mato Grosso do Sul.

\section{ABSTRACT}

THIS WORK HAS AMONG ITS OBJECTIVES TO LAUNCH A REFLECTIVE ANALYSIS ON THE SITUATION OF INDIGENOUS PRISONERS IN DOURADOS, STATE OF MATO GROSSO DO SUL, BRAZIL. IT IS NOTEWORTHY THAT THE THEORETICAL PROBLEM IS BASED ON THE FACT THAT, ALTHOUGH THERE ARE NUMEROUS LEGAL TEXTS, PACTS, PROTOCOLS, AND SIMILAR STATEMENTS, BOTH NATIONAL, AND INTERNATIONAL, TO PROTECT THE RIGHTS OF INDIGENOUS PEOPLES, THERE ARE CONSTANTS VIOLATIONS OF THOSE RIGHTS THAT BELONG TO THE UNIVERSALITY OF HUMAN RIGHTS. THEREFORE, QUESTIONS ARISE SUCH AS: WHAT IS THE GAP THAT PREVENTS THE PROPER IMPLEMENTATION OF THE RIGHTS OF INDIGENOUS PEOPLES FROM THE INDIGENOUS PRISON POPULATION IN THE STATE OF MATO GROSSO DO SUL? FOR THE CONSTRUCTION OF THIS TEXT APPEALED TO CONTRIBUTIONS FROM VARIOUS DISCIPLINES SUCH AS CONSTITUTIONAL LAW, CRIMINAL LAW, INTERNATIONAL LAW AND HUMAN RIGHTS, BECAUSE THEY ARE CLOSELY INTERCONNECTED WITH THE PROTECTION OF THE RIGHTS OF INDIGENOUS PEOPLES. THE RIGHTS ADDRESSED HERE, IS BY MEANS OF AN INTERDISCIPLINARY PERSPECTIVE ON THE VARIOUS AREAS OF KNOWLEDGE, AIMING TO MAKE PROGRESS IN UNDERSTANDING THIS ISSUE, MAKING A SPECIAL REFERENCE TO THE LEGAL ANTHROPOLOGY. THE METHOD USED, WAS THE DESCRIPTIVE-ANALYTICAL METHOD, APPLYING THE DOCUMENTARY ANALYSIS AND LITERATURE TO THE CASE. APART FROM THAT WE USE CASE STUDIES, AS PROPOSED IN ETHNOGRAPHY AND LOCAL LEGAL PRACTICE, WHEN IT COMES TO STUDYING DIVERSE CULTURES.

\section{KEYWORDS}

DIVERSITY; INDIGENOUS PEOPLES; PRISON POLICIES; HUMAN RIGHTS; StATE of MATO GROSSO DO SUL. 
LABACENIGI ANE GOGEGUI

OWIIDI NIGICOA, GONIGENATAKENIGICO, MOKO NOIKA, PIDA AGICA DAGA ODEMITETIGUI. JINATAGA, NIGINOA NOKODODI ELIODI ME JAWIKODEGA, LEgODI, AGICA ANALEgAGA NOLETOGOLOCO, JOANIGIDAA LEEGODI ME ETI GODIBOLOITEE. ANE LOWOOGO GOBAKEDI, JEMANAGA, ME IDATAWEEKE OIYWOGODI ANE LAWIKODICO NIGINA NOIKIGUI NIWILOGOJEGUI. JIKENAGA ANODAGEE NOIGUI GAIWÁ, NIJOLOLE INA GUARANÍ, LEGODI, JIGINAGI MINATGA NOIGI, NIGICOA NIWILOGOJEDI ANE OWIDITIWAJI. NidAgIDA ME JABAKENAGATELOCO, LAWIKODIGUI, NIGINA NOKIGUI ANE DINIWILO, JEMANGA ME JIKENAGA, NIGICOA GONIGENATAKENIGICO, ANEDAGA ONELOGOITEDOGOA CODAA ANEDAGA ODEMITETIGUI, NIGINA ME IDATECIBECE ME DINIWILO NOIKIGUI.

NOTAGA ANE JIBAKENAGA

NOIKA,GONIGENATAKEGICO, NIWILOGONAGAXIDI.

"As pessoas e os grupos sociais têm o direito a ser iguais quando a diferença os inferioriza, e o direito a ser diferentes quando a igualdade os descaracteriza."

Boaventura de Sousa Santos

\section{INTRODUÇÃO}

A Constituição Federal de 1988 dedicou um capítulo específico de direitos aos povos indígenas (Cap. VIII - Dos Índios), reconhecendo sua diversidade cultural e sua forma de organização, deixando claro não apenas o respeito, mas também a especificidade das questões relacionadas a esses povos no território brasileiro. Esse tratamento especial que a Constituição Federal de 1988 consagrou aos povos indígenas é resultado de amplo acordo político que envolveu partidos políticos, segmentos da sociedade civil, bem como movimentos apoiadores interessados na questão indígena durante a Assembleia Nacional Constituinte, possibilitando um incremento da proteção dos direitos humanos e mais especificamente da proteção dos direitos dos povos indígenas no Brasil.

O presente trabalho tem entre seus objetivos levar ao conhecimento da sociedade, em especial à jurídica, às sérias violações que vem sofrendo os povos indígenas no que diz respeito a seus direitos e garantias constitucionais e infraconstitucionais. Para tanto, utilizaremos um estudo de caso sobre a população carcerária indígena do Município de Dourados, MS. A escolha desse município deve-se ao fato de que se localiza nessa região uma das aldeias mais densamente povoadas do Brasil, a Aldeia Jaguapiru, que abriga a maior população carcerária indígena do país.

Sabe-se que os povos indígenas estão divididos em várias etnias, que se diferenciam por culturas, línguas e organizações sociais e políticas. No entanto, toda essa sociedade indígena tem em comum uma história de exploração econômica, social e cultural. Atualmente existem no Brasil 236 povos, falantes de mais de 180 línguas 
diferentes. Os povos indígenas somam, segundo o Censo IBGE 2010, 817.963 pessoas. Destas, 315.180 vivem em cidades e 502.783, em áreas rurais; isso corresponde aproximadamente a $0,42 \%$ da população total do País. A maior parte dessa população distribui-se por milhares de aldeias, situadas no interior de 673 terras indígenas de norte a sul do território nacional. Os indígenas, perfazem cerca de 0,25\% da população brasileira ${ }^{1}$ e o Estado de Mato Grosso do Sul, por sua vez, possui a segunda maior população indígena do país.

Durante o processo da formação da Nação brasileira, a história nos aponta que se ensaiava um discurso de proteção aos direitos indígenas que se repetiria inocuamente em inúmeras leis, cartas, decretos e alvarás, durante todo o período colonial, monárquico e republicano. Entretanto, a situação somente começaria a mudar positivamente com a Constituição de 1988, passando-se do plano teórico à efetivação dos direitos indígenas. Desse modo, foram-se construindo institutos jurídicos que puderam enquadrar as populações indígenas distribuídas pelo território historicamente denominado brasileiro (Souza Filho, 1999).

Ao fazermos uma digressão histórica, percebemos que já no início do século XX o Brasil passou a ter uma ação governamental protecionista frente os seus povos indígenas, embasada em um pretexto assistencialista que apresenta restrições aos direitos civis dos indígenas, como bem se podia observar no artigo $6^{\circ}$ do Código Civil ${ }^{2}$ de 1916, que concedia aos povos indígenas, dito "silvícolas", a condição jurídica de relativamente incapazes para realizar certos atos da vida civil, sujeitando-os a um regime tutelar especial.

Pode-se dizer que as repúblicas latino-americanas de uma maneira geral, e particularmente o Brasil, erigiram-se assentadas sobre o mesmo substrato, reeditando a diferença racial que recebeu o nome de colonialismo interno. A ficção de um Estado homogêneo, contudo, se nota cada vez mais insustentável e, o que nos últimos anos se intenta cobrir com expressões de liberalismo jurídico, na realidade, é senão outra forma de seguir tentando anular o indígena através de uma "colonização jurídica" (Pacheco, 2006).

Diante de um cenário de desconsideração cultural e legal para com as populações indígenas, surge um quadro de destituição e de violência para com estes no Brasil, pois o Estado contemporâneo e seu direito vêm negando a possibilidade de convivência de sistemas jurídicos diferentes; como no caso o direito consuetudinário dos povos indígenas (direito indígena per se) e o direito nacional "não indígena”, ou direito indigenista, elaborado pelo não índio, para o índio.

É importante levar em consideração que cada povo, etnia e comunidade indígena possui seu próprio direito consuetudinário, e muitas soluções e também lições podem ser retiradas daí, como a utilização de meios sancionadores próprios para infrações cometidas por um membro da comunidade. Como bem indica a Convenção n.169 da OIT, $^{3}$ de 1989, que enfatiza a garantia dos povos indígenas em conservar 
sua cultura e seus costumes, e utilizar suas próprias instituições, inclusive jurídicas, de direito consuetudinário. ${ }^{4}$

Sendo assim, ao mesmo tempo em que a construção do direito pátrio manteve como inexistente qualquer manifestação jurídica das sociedades indígenas, foram sendo construídos institutos próprios para eles, cujo conjunto se convencionou chamar de direito indigenista, em detrimento do direito indígena, ou direito consuetudinário dos povos indígenas, como bem salienta Souza Filho (1992, p. 20). Infelizmente, é dentro dessa configuração que os povos indígenas se inserem, ainda que de forma coercitiva por parte do Poder Público, o qual, na maioria das vezes não está preparado para lidar com as especificidades dos povos indígenas.

\section{PROTEÇÃO JURÍdiCA DOS DIREITOS DOS POVOS INDÍGENAS}

\section{I NORMAS NACIONAIS DE PROTEÇÃO DOS DIREITOS DOS POVOS INDÍGENAS}

\section{i. i. i O novo paradigma trazido pela Constituição Federal de 5/ i o/ i 988}

Conforme já registrado, com a vigência da Constituição Federal de 1988, os povos indígenas no Brasil tiveram restringidos seus direitos, pois não se permitia qualquer outro regime diferenciado que acolhesse a sua diversidade cultural. Nesse contexto, as entidades indígenas ficavam submetidas a um regime tutelar, pois o Estado tinha como intenção eliminar toda a diversidade que esses povos apresentavam por meio de sua assimilação e incorporação à sociedade nacional. ${ }^{5}$

Essa política indigenista foi articulada pelo então Serviço de Proteção ao Índio (SPI), criado em 1910 para regular a política referente a esses povos, os quais durante grande parte do século XX estiveram sob constante a ameaça de desaparecimento de suas culturas, pois eram coagidos a renunciar aos seus próprios costumes e se integrarem à comunhão nacional, ao mainstream. A perspectiva que se tinha à época era de que os povos indígenas possuíam o discernimento incompleto ou em fase de desenvolvimento, e não se respeitaria a forma diferenciada em que essas sociedades viviam.

Nesse sentido, pode-se dizer que a Constituição Federal de 1988 traz em seu Capítulo VIII, Título VII, a finalidade de transformar e reconhecer as sociedades indígenas e garantir-lhes o preceito constitucional como sujeitos do tratamento especial, como bem se pode verificar a seguir:

A Constituição Federal de 1988 consolida o marco da mudança de paradigma na política indigenista oficial brasileira, fornecendo os elementos norteadores do respeito à diferença cultural dos povos. Dois artigos foram dedicados especificamente à determinação dos direitos 
indígenas: Art.231. São reconhecidos aos índios a sua organização social, costumes, línguas, crenças e tradições, e os direitos originários sobre as terras que tradicionalmente ocupam, competindo à união demarcá-las, e fazer respeitar todos os seus bens (CTI, 2008, p. 23).

Trata-se do reconhecimento à diferença, por meio do qual a cultura passa a integrar o patrimônio cultural brasileiro. A Constituição Federal de 1988 reconheceu também aos povos indígenas, sua organização social, seus costumes, línguas, crenças e tradições, delegando à União o dever de proteger e fazer respeitar todos esses bens (art. 231, caput).

Note-se, portanto, que o processo de erradicação e assimilação das culturas indígenas objetivados pelo Estado, não obteve êxito, pois as diversas etnias têm resistido de forma incansável, obtendo através da própria Constituição Federal de 1988 o reconhecimento de um modo de vida peculiar:

À luz da Constituição em vigor, portanto, os povos indígenas deixaram de ser consideradas culturas em extinção, fadadas à incorporação na assim denominada comunhão nacional, nos moldes do que sempre fora o espírito a reger a legislação brasileira desde o início do processo de colonização em nosso país. Toda a legislação anterior continha referências expressas à integração ou à assimilação inevitável e, por outro lado, desejável dos índios pela sociedade brasileira. A nova mentalidade assegura espaço para uma interação entre os povos e a sociedade envolvente em condições de igualdade, pois que se funda na garantia do direito à diferença (Leitão, 1993, p. 228, grifo nosso).

É possível afirmar que a Constituição de 1988 consagrou os direitos dos índios e das comunidades indígenas, inclusive o direito à identidade cultural e o direito à ocupação permanente da terra e à exclusividade no uso de seus recursos e na exploração de suas riquezas. Do ponto de vista da garantia desses direitos, dois pontos merecem especial referência, e um deles foi a atribuição de competência à Justiça Federal para as questões que envolvam os direitos dos povos indígenas. ${ }^{6}$

Outra inovação importante que a Constituição Federal de 1988 trouxe foi a atribuição constitucional de competência ao Ministério Público Federal (MPF) para a defesa dos direitos dos índios. Segundo o artigo 129 da Constituição Federal, umas das funções do MPF “é defender judicialmente os direitos e interesses das populações indígenas”. Atualmente isso se vem dando pela atuação da $6^{\text {a }}$ Câmara de Coordenação e Revisão do Ministério Público Federal. Dessa forma, a proteção à diversidade cultural dos povos indígenas, cujos valores passaram a ser objeto de tutela constitucional vem sendo efetivada no Brasil por esse órgão. 
I. I. 2 A Lei N. 600 I/73, Estatuto do Índio

O Estatuto do Índio, por seu turno, é uma lei ordinária que tem por objetivo regulamentar a situação jurídica dos índios e das comunidades indígenas no Brasil; ele foi elaborado num momento em que o País era dominado por um regime autoritário que não permitia a participação dos diversos setores da sociedade civil na elaboração e na execução de suas políticas públicas oficiais.

A sua elaboração remonta quinze anos antes da promulgação da Constituição Federal de 1988, e segue em vigor - não passou por nenhuma reforma ou revisão depois da promulgação da CF de 1988 -, mantendo em seu texto o mesmo pensamento tutelar e integracionista. O objetivo integracionista pode ser observado logo no seu primeiro artigo, quando se menciona: "Esta lei regula a situação jurídica dos índios ou silvícolas e das comunidades indígenas, com o propósito de preservar a sua cultura e integrá-los, progressiva e harmoniosamente, á cultura nacional" (grifo nosso).

Cabe ressaltar que ao tratar da Lei n. 6001/73 - Estatuto do Índio, está-se referindo ao que se convencionou chamar por alguns autores brasileiros, como Antunes (1998), Santos Filho (2005) e Barreto (2003), de direito indigenista. ${ }^{7}$ De acordo com tais autores, trata-se de uma disciplina autônoma, um ramo do direito positivo, por se tratar de um sistema positivado de normas postas em favor dos índios e suas comunidades, considerando a Constituição Federal de 1988 o marco legal em relação aos direitos desses povos.

Entendemos, entretanto, que o direito indigenista não pode mais ser o resultado do simples processo legislativo nacional, feito de fora para dentro pela sociedade abrangente, sem se dar ouvidos aos anseios, às necessidade e à realidade dos povos indígenas que habitam o território Nacional. Acreditamos que a utilização do termo direito indigenista não seja o mais adequado, dada a divisão que ele cria ao se contrapor ao termo direitos indígenas. ${ }^{8}$ Por mais que se acredite na boa intenção em disciplinar a matéria, a utilização desse termo dá a entender, grosso modo, de que se trata de "lei de não indígena, feita para indígena", o que não pode ser, pois se estaria olvidando que os direitos dos povos indígenas formam parte indissociável do acervo dos direitos humanos.

Insta lembrar que os direitos dos povos indígenas são direitos humanos, que por sua vez formam uma unidade indivisível, interdependente e inter-relacionada, capaz de conjugar o catálogo de direitos civis e políticos ao catálogo de direitos sociais, econômicos e culturais (Piovesan, 2001). Cançado Trindade (1997) reforça: "a indivisibilidade e a interdependência de todos os direitos humanos devem ser analisadas à luz da unidade fundamental de concepção dos direitos humanos", e não podem ficar estes refém de subterfúgios eufemísticos.

Embora ainda esteja em vigor, o atual Estatuto do Índio está obsoleto e não é de forma alguma uníssono ao espírito da Constituição Federal de 1988. Alguns conceitos que permeiam a Lei 6001/73 ainda estão mal esclarecidos; isso traz 
sérios prejuízos, em especial para o operador do direito, para que este possa aplicá-lo satisfatoriamente em benefício dos indígenas. Para exemplificar citamos o artigo $4^{\circ}$, a Lei $6001 / 73$ que trata dos povos indígenas sob categorias de: índios isolados, em vias de integração e integrados.

Por certo essa classificação advém do conceito de integração que tinham os legisladores da época, e que por meio de um imaginário próprio e essencialista viam os indígenas, como o "índio puro", "legítimo”, sob a óptica do Indianismo Romântico alencariano do século XIX ${ }^{9}$ que se baseava na crença infundada de que, em se apropriando de qualquer traço da cultura material (artefatos) ou da cultura imaterial (linguagem, valores, comportamentos) do mundo dos não indígenas, os indígenas deixariam de ser o que eram (Ferreira Lima, 2007).

Nesse sentido, aponta-se a questão da identidade indígena como um fator essencial a ser considerado pelos operadores do direito. Ser índio é, antes de tudo, ser considerado índio por si mesmo e pela própria comunidade em que está inserido. Esse pertencimento implica características culturais, mas isso não significa que estas sejam estanques, imóveis. A cultura é considerada essencialmente dinâmica e constantemente reelaborada (Barth, 2000, p. 35), grupos indígenas continuam com suas identidades étnicas distintas, mesmo que se articulem com a sociedade nacional (Castilho e Paranhos, 2003, p. 3-4).

Muitos indivíduos que se consideram indígenas, mas não possuem traços fenótipos aceitos como indígena, ao conviverem com e entre o grupo, podem ser considerado pelos demais como um de seus pares:

Essa conceituação é discutível, mas tem pelo menos o mérito de consignar que é índio aquele indivíduo que é reconhecido pelos índios como índio também, o que é um bom referencial antropológico. Esse reconhecimento manifestado pelo constituinte refere-se aos índios, cabendo ter por certo que índio, para o direito brasileiro, não é só aquele nacional descrito na legislação infraconstitucional, mas todo aquele que pela expressão constitucional dos arts. 231 e 232 reúna características jurídicoantropológicas que como tal o identifiquem. Em outros termos índio não é só aquele que a definição legal identifica senão aqueles reconhecidos pela sua comunidade e os que, por sua organização social, costumes, tradições e crenças, possam assim ser (Castilho e Paranhos, 2003, p. 45).

Esse novo referencial, ao ser aplicado aos direitos relativos aos povos indígenas, encontra alguns obstáculos, como descreve o antropólogo Darcy Ribeiro (1970, p. 196), “a ideologia brasileira quer o índio como um futuro 'branco' dissolvido pela amalgamação racial e pela assimilação na comunidade nacional”. Essa "ideologia” vista por Ribeiro continua presente ainda hoje, podendo se fazer sentir no enorme desprezo dos 
operadores do sistema penal para com os dispositivos normativos positivados que garantem um tratamento diferenciado aos indígenas (Silva Filho, apud Lacerda, 2007, p. 221). Em outras palavras, a nova perspectiva de se vislumbrar os povos indígenas implica mudanças socioculturais nas formas de organização desses grupos, não significa dizer que os indígenas deixam de ser indígenas ou perdem suas identidades, caso haja uma interação com a sociedade não-indígena.

É importante destacar que enquanto a Lei $6001 / 73$ se pautava em ditames das teorias assimilacionistas, os ordenamentos jurídicos mais recentes acolheram outro referencial teórico que respeita a autodefinição e o pertencimento do próprio indígena. Pode-se aqui apontar como novo e efetivo referencial para o tema: a Constituição Federal de 1988; a Convenção 169 sobre Povos Indígenas e Tribais em Países Independentes, da Organização Internacional do Trabalho, OIT, ${ }^{10}$ aprovada em 1989 e internalizada no Ordenamento Jurídico brasileiro pelo DecretoLegislativo n. 143/2002 e Decreto Federal n. 5.051, de 19 de abril de 2004; e ainda, a recente Declaração das Nações Unidas sobre o Direito dos Povos Indígenas, aprovada pela Assembleia Geral das Nações Unidas em setembro de 2007.

A Constituição Federal de 1988 reconheceu expressamente aos índios, suas organizações sociais, usos, costumes, tradições, direito ao território, capacidade para postular em juízo, bem como legitima o direito às diferenças étnico-culturais. Por seu turno, a Convenção 169 da OIT declara que a condição de indígena não advém de parâmetros externos, mas sim de um processo de autodefinição: "a consciência de sua identidade indígena ou tribal deverá ser considerada como critério fundamental para determinar os grupos aos quais se aplicam as disposições da presente Convenção” (item 2, art. $1^{\mathrm{o}}$ ).

\section{I.2 NORMAS INTERNACIONAIS DE PROTEÇÃO DOS DIREITOS DOS POVOS INDÍGENAS}

\section{I.2. I As Convenções N. i o7 E i 69 da Organização Internacional do Trabalho}

Qual teria sido o motivo que levou uma organização internacional que tem como principal objetivo regular o sistema internacional do trabalho, como é a OIT, a se interessar pelo direito dos povos indígenas? A princípio, pode-se dizer que foi regrar as relações trabalhistas dos povos indígenas e que lhes fosse aplicado o princípio da isonomia, levando em consideração o seu estatuto diferenciado dentro da sociedade abrangente, para evitar que seus direitos como trabalhadores fossem desrespeitados nos países que estavam se tornando independentes durante o século XX. Ou seja, para evitar que os povos indígenas fossem espoliados de meios de subsistência conforme suas necessidades e interesses - em razão da subtração e espoliação de suas terras -, e explorados em sua mão de obra.

A Convenção n.107 da OIT, primeira a ser adotada sobre a matéria, reflete o discurso dominante paternalista na época da descolonização sobre os povos indígenas, 
com cláusulas que pregam a integração e assimilação progressiva desses povos na sociedade abrangente do Estado signatário. ${ }^{11}$

$\mathrm{O}$ artigo $5^{\circ}$ da Convenção 169 da OIT determina que deverão ser reconhecidos e protegidos os valores e práticas sociais, culturais, religiosas e espirituais dos índios e que deverão ser tomadas devidamente em consideração a índole dos problemas que se lhes colocam, coletiva e individualmente, e que deverá ser respeitada a integridade dos valores, práticas e instituições desses povos. Isso também já está garantido pela lei específica e pela Constituição do Brasil.

A Convenção 169 surge reforçando uma situação que já tinha sido tratada pela Constituição Federal de 1988, no que se refere à respeitabilidade das culturas indígenas, como indica Barbosa (2001, p. 233): “O artigo $8^{\circ}$ da Convenção também dispõe que ao se aplicar a legislação nacional aos povos indígenas deverão ser tomados devidamente em consideração os seus costumes ou seu direito costumeiro princípio este harmônico com a constituição e a lei brasileiras”.

\section{i. 2. 2 A Declaração das Nações Unidas sobre os Direitos}

Dos Povos Indígenas

Após 25 anos de longos e intricados debates, a Assembleia Geral das Nações Unidas aprovou em setembro de 2007 por 143 votos a favor, quatro contra e onze abstenções, uma declaração solene especificamente sobre o direito dos povos indígenas. ${ }^{12}$

Embora não possua força jurídica obrigatória, a Declaração sobre os Direitos dos Povos Indígenas tem incontestavelmente um grande peso político e moral, ainda mais no continente americano. As declarações, que são resoluções recomendatórias de organizações internacionais, são classificadas como instrumentos de soft law, o que significa, ao invés da hard law e apesar da sua natureza solene, que não possuem caráter vinculante. Isto verifica-se perfeitamente na prática, nomeadamente da ONU, onde a declaração apresenta-se como um instrumento oficial adequado para ocasiões muito especiais, e servindo para enunciar princípios de importância permanente (Maia e Oliveira do Prado, 2011).

Os direitos reconhecidos por declarações podem transcender a falta de força obrigatória do seu suporte formal, criando uma prática geral aceita como juridicamente vinculante, ou seja, passando a converter-se em direitos consuetudinários. Destaque-se o artigo $2^{\circ}$ da Declaração das Nações Unidas, que trata do reconhecimento e do respeito à diversidade étnico-cultural: "Os povos indígenas são livres e iguais a todos os demais povos e pessoas e têm o direito de não ser objeto de nenhuma discriminação no exercício de seus direitos fundado em particular, em sua origem ou identidade indígena”. Note-se que o dispositivo legal, ao afirmar que os povos indígenas são iguais a todos os demais povos, reconhece ao mesmo tempo o direito de todos os povos a serem diferentes, a considerarem a si mesmos diferentes e serem respeitados como tais. 
Reconhece-se, portanto, a urgente necessidade de respeitar e promover os direitos intrínsecos dos povos indígenas, que derivam de suas próprias estruturas políticas, econômicas e sociais e de suas culturas, tradições espirituais, história e concepção de vida (Lacerda, 2007).

Ressalte-se, sobretudo, a necessidade de respeitar e promover os direitos dos povos indígenas assegurados em tratados, acordos e outros pactos construtivos com os Estados, reconhecendo também que o respeito aos conhecimentos, às culturas e às práticas tradicionais indígenas contribui para o desenvolvimento sustentável.

\section{SITUAÇÃO DOS PRESOS INDÍGENAS NO MUNICÍPIO DE DOURADOS, MS}

\section{I CONFlitos TERritoriais, POPULAÇÃo CARCERÁRia}

De acordo com a vice-procuradora-geral da República, Dra. Deborah Duprat, o Estado de Mato Grosso do Sul é o Estado com a segunda maior população indígena do Brasil (cerca de 70 mil indivíduos) e concentra, atualmente, os maiores problemas sociais e conflitos por demarcação de terras.

Conforme estudos de especialistas - em especial de acordo com estudos de Dra. Deborah Duprat (2010), então coordenadora da $6^{\text {a }}$ Câmara de Coordenação e Revisão (CCR), que trata de assuntos relativos aos povos indígenas e outras minorias étnicas -, em um encontro realizado em Campo Grande, capital do Estado, afirmouse que: "o problema das comunidades indígenas está intimamente ligado à insuficiência de terras e (...) a situação em Dourados/MS, além de indigna, é a maior tragédia mundial conhecida na questão indígena”.

Ao tratar deste tema, e de acordo com pesquisas recentes o Centro de Trabalho Indigenista (CTI, 2008), uma das principais causas dos problemas que envolvem os povos indígenas e o incremento da população carcerária indígena em Dourados/MS é redução do espaço vital de seus territórios tradicionais. ${ }^{13}$

A Reserva Indígena de Dourados, assim como tantas outras criadas no início do século XX pela política indigenista, foi estabelecida com o firme propósito de "confinamento". Essas Reservas eram locais para onde os indígenas deveriam se dirigir, de livre vontade ou sob ameaças e pressões (Pacheco 2004). Eles deveriam ser transferidos de suas terras, até estarem prontos a integrar-se à sociedade envolvente. A ideia de criar reservas não significava que se havia optado por criar um espaço territorial digno, mas sim de liberar terras para as frentes de expansão agrícola de colonização interna, que iniciava naquele começo de século a ocupar terras no então Estado de Mato Grosso.

Com essa política implantada pelo Estado, os indígenas viram suas terras sendo invadidas, foram expropriados de seus territórios tradicionais e tinham de abrigar-se nas Reservas construídas pelo Estado. 
Essa situação se agravou principalmente na segunda metade do século XX. Segundo historiadores, (Brand, 2001 e Pacheco 2001) esse processo de "confinamento" se radicalizou a partir da década de 1970, com a chegada das grandes lavouras e da consequente mecanização da atividade agrícola. Atualmente, esses indígenas que vivem "confinados" nos limites de suas áreas indígenas dedicam-se principalmente ao corte da cana-de-açúcar, visto que este Estado hoje abriga grandes usinas sucroalcooleiras.

Some-se a isso o fato de que fazendeiros locais e o próprio governo estadual têm tentado, por meio de políticas públicas, flexibilizar e reduzir ainda mais as terras dessas comunidades:

1 (...) Reclamações idênticas vieram dos índios do PI de Dourados, segundo os quais, em 1975, haviam desaparecido 61 hectares da área inicialmente demarcada. Insistiram os índios nesse período na reaviventação dos limites originais das reservas, exatamente por causas dessas reduções:

2 Essas reduções foram efetivamente realizadas em 1990 e 1991, mediante convênio entre a Funai e o Terrasul, MS. Mas, ao invés de devolverem as terras griladas, confirmaram as terras reduzidas (Brand, 2001, p. 122).

Na construção das Reservas Indígenas, tal qual foi proposta pela política indigenista, apresenta-se, além do conflito entre indígenas e não indígenas, o conflito entre indígenas de várias etnias. A política das reservas não respeitou as diferenças e colocou em uma mesma Terra Indígena, no caso da área de Dourados, três etnias indígenas distintas. Isso se deve ao fato de que o senso comum vê o indígena como um "índio genérico", e coloca todos os indivíduos sob o mesmo rótulo, transformando uma categoria social tão diversa em algo homogêneo.

É crucial compreender que cada etnia traz consigo características próprias, especificidades configuradas a partir de realidades linguísticas, históricas, ecológicas e cosmogônicas distintas.

A realidade em que se encontram os indígenas, em especial os da Reserva de Dourados, MS, é desoladora. Não se vislumbram perspectivas alentadoras e, diante de um quadro social extremamente tenso e conflituoso, problemas como alcoolismo e o consumo de drogas ilícitas geram violência e instabilidade, como se pode verificar no relatório do CTI (2008), Situação dos Detentos Indígenas no Mato Grosso do Sul:

Os suicídios e as tentativas de suicídio tão recorrentes nos últimos anos entre os Kaiowá e Guarani, as mortes de crianças por desnutrição e as 
elevadas taxas de criminalidade que afligem os índios são uma das consequências da constante pressão exercida sobre estas populações por parte das diferentes frentes de expansão econômica na região: um cenário histórico de exploração, opressão desrespeito à diversidade por parte do poder público e da sociedade envolvente de maneira geral (CTI, 2008, p. 15).

Com a política territorial imposta pelo Governo Federal, hodiernamente, o município de Dourados concentra a maior densidade de indígenas do Brasil, com uma área de aproximadamente 3.500 hectares de terra para uma população de mais de 12 mil indígenas (Agência Brasil, 2008).

Deve-se levar em consideração que o processo de "desenvolvimento" econômico adotado pelo município de Dourados tem pressionado sobremaneira as áreas indígenas próximas. De acordo com o trabalho realizado pelo CTI (2008), a pressão urbana e seus consequentes problemas, como a marginalização, aumentaram a prática de crimes entre os povos indígenas na região da Grande Dourados. ${ }^{14}$

\section{2. i. i Situação Jurídica dos presos indígenas de Dourados}

A situação dos acusados e sentenciados indígenas, de acordo com os levantamentos realizados para este estudo, indica que os presos indígenas no Estado de Mato Grosso do Sul estão sendo vítimas de violações de direitos e garantias constitucionais em face da falta ou deficiência de assistência jurídica.

Segundo dados do CTI (2008), do total de indígenas envolvidos em crimes na região (vide Anexos I e II), apenas 22\% receberam a devida e adequada assistência jurídica, incluindo nestes dados a não presença de intérprete judicial, em cumprimento do dispositivo legal do artigo 12 da Convenção 169 da OIT, ${ }^{15}$ como já dito, já devidamente parte do Ordenamento Jurídico nacional.

Para ilustrar o descaso, trazemos a lume a situação jurídico-penal vivenciada pelos detentos indígenas. Para este fim, é importante levar em consideração a forma que a legislação e, em especial, o Direito Penal foram "construídos" e aplicados.

O Direito Penal não tem acompanhado, no mesmo ritmo, as conquistas incluídas nas últimas décadas pelo Direito Constitucional e pelos Tratados Internacionais que reconhecem um pluralismo cultural, legal, linguístico e a igual dignidade de culturas. No Direito Penal há uma exclusão da cultura e modo de vida dos povos indígenas, uma vez que não se reconhece o direito indígena como outro sistema jurídico.

No Brasil, como em outros países da América Latina, o Direito Penal sempre encontrou fundamento em um positivismo racionalista ocidental, com a importação de legislação e doutrina europeias (tanto nos casos de Civil Law como de Common Law) para acomodar a realidade indígena. 
A Fundação Nacional do Índio (Funai), criada em 1967 para substituir o Serviço de Proteção ao Índio (SPI), sempre tratou das questões pertinentes aos indígenas. Ocorre que essa Fundação, no caso do Estado de Mato Grosso do Sul, conta com um único servidor, um Procurador Federal, para atender mais de trinta áreas indígenas no cone sul do Estado. Um único agente para dar assessoria jurídica a mais de 35 mil indígenas de diversas etnias.

Segundo o relatório do CTI (2008), os indígenas processados por delito de homicídio - crime sujeito ao procedimento do júri -, devido à defesa insuficiente acabam sendo pronunciados e, quando julgados pelo Tribunal do Júri - cujos jurados e juradas, muitas vezes, desconhecem os modos de percepção e práticas sociais indígenas -, geralmente são condenados.

É na fase processual, e principalmente por falta de um acompanhamento jurídico adequado, que muitos indígenas deixam de comparecer às audiências como testemunhas; os prazos não são observados e, muitas vezes, devido à omissão são processados ou conduzidos a juízo coercitivamente (CIT, 2008). Os indígenas processados, ao deixarem de comparecer, são declarados revéis e acabam tendo suas prisões decretadas preventivamente, ou seja, antes da condenação irrecorrível.

Com as considerações levantadas pelo trabalho do CTI (2008), além de pesquisas bibliográficas e de campo feitas para este trabalho, percebe-se que há uma lacuna entre o que a Justiça almeja e o que realmente é efetivado para com os indígenas.

Para elucidar essa situação, buscamos referenciais em perícias antropológicas, dentre elas cita-se uma realizada para o Ministério Público do Trabalho (MPT), na qual o problema investigado era a "capacidade sociopsicológica e cultural” dos índios da aldeia Tey Kuê, localizada no município de Caarapó, MS, mais precisamente dos indígenas $\mathrm{S}$. V. (iniciais) (processo n. 1136/2003) e S. B. (iniciais) (processo n. 1128/2003). A dúvida que se apresentava ao perito do MPF era saber se esses indígenas tinham condições de compreender as instruções processuais apresentadas durantes as audiências.

O perito judicial advertiu que a questão relativa aos prazos a serem cumpridos pelos indígenas diante da Justiça era um fator a ser observado com acuidade. Os prazos prescricionais, por exemplo, geralmente não são cumpridos, uma vez que o indígena, em sua cultura e de acordo com seu modo de ser, apresenta uma forma diferente da percepção do mundo "ocidental" na forma de lidar com o tempo (Ferreira de Lima, 2007).

O mesmo perito aduz que "o analista incauto poderia apressar-se em concluir que a perda de prazos e o ritmo Guarani que, à nossa óptica, nos parece lento, seria peculiar apenas aos índios residentes nas áreas mais recônditas da reserva ou àqueles destituídos de maior educação formal", porém, "não é o que ocorre" (Ferreira de Lima, 2007, p.49). Segundo a afirmação da professora do Magistério Superior Indígena, que foi mencionada na perícia antropológica citada e a qual acompanha aos indígenas há mais de sete anos: 
O tempo deles é diferente do nosso. Olhe os professores indígenas que estão ali, na frente, com um monte de informação e tal, mas, por exemplo, você marca um prazo para eles: olha, até tal dia você tem que me entregar a documentação para o teu contrato aqui na Secretaria de Educação. Tem professor aqui olha, já estou aqui há sete anos e está com o CPF cancelado porque ele não renovou, não cadastrou o CPF. E ele só vai perceber isso quando cortam o pagamento dele.

Ferreira de Lima (2007) referiu-se que a capacidade cognitiva varia com a organização social, com a cultura de cada povo, com a variabilidade ecológica, o contexto histórico, o universo linguístico. Nestas sociedades ditas "tradicionais" o pensamento se ancora no concreto, isso poderia levar à conclusão de que esses indivíduos teriam maneiras diferentes de entender a realidade e sentiriam mais dificuldade de compreender dados abstratos, como os prazos em geral.

\subsection{Desafios Na APliCAÇÃo do Direito Indigenista}

Embora a Funai trate das questões jurídicas pertinentes aos indígenas, atualmente têm surgido organizações que trabalham no sentido de minimizar os problemas enfrentados por esses povos.

Vale sublinhar a importante ação do Projeto Dorvalino Rocha, do Centro de Defesa da Cidadania e dos Direitos Humanos Marçal de Souza Tupã-i, MS, que oferece orientação jurídica e assistência judicial através de advogado aos indígenas que buscam o Centro, que os acompanha conforme as especificidades de cada caso. No que diz respeito à área de atuação, é importante mencionar que os acompanhamentos vão desde a esfera administrativa até a contenciosa.

Sob o aspecto técnico, os acompanhamentos não se limitam a uma ou outra área do direito, ou seja, os atendimentos englobam praticamente todas as áreas do direito e zelam pela defesa dos interesses daqueles que tanto necessitam.

Em relação ao entendimento e aplicação da legislação específica inerente aos indígenas, nota-se que o Poder Judiciário, principalmente local, ainda possui uma grande resistência, e até mesmo falta de conhecimento, e algumas vezes está contaminado pelos estereótipos e preconceitos históricos relativos aos povos indígenas.

$\mathrm{Na}$ verdade, tem-se notado que, quando se invoca a legislação específica, os magistrados e alguns membros do Ministério Público deixam de verificar a questão com maior profundidade e limitam-se a aplicar a legislação "geral”, justificando tal posicionamento em razão de o indígena supostamente estar "integrado” à comunhão nacional, o que demonstra a urgência da reforma da Lei 6001/73, O Estatuto do Índio.

Um claro exemplo da não aplicação do direito indigenista é o procedimento adotado no interrogatório policial. Nestes casos, a autoridade não utiliza o auxílio de um intérprete a maior parte das vezes, deixando de seguir a orientação estabelecida no 
artigo 12 da Convenção 169 da OIT, a saber: "Artigo 12. (...) Deverão ser adotadas medidas para que os membros desses povos possam compreender e se fazer compreender em procedimentos legais facilitando para eles se for necessário intérprete ou outros meios necessários (grifo nosso).

Os presos indígenas que são recolhidos aos presídios e cadeias públicas da Grande Dourados passam por várias “situações-problema” dentre as quais destacamos: (1) a falta de compreensão da língua não indígena, a falta de comunicação impede a real promoção e acesso à Justiça; (2) a dificuldade de compreender as formalidades do sistema judicial e suas simbologias (Bourdieu, 2003) e; (3) discriminação, fato que é comum à pessoa do indígena no âmbito social:

Nas audiências criminais, há situações em que o indígena não consegue dizer uma só palavra, por falta de orientação. Por ocasião da oitiva, o Procurador da Funai é citado, mas não comparece no dia, local e data, pois não tem como estar em várias Comarcas ao mesmo tempo(CTI, 2008, p. 31).

Quando eles prendem, é, as pessoas, inclusive aqui eu tenho um tio meu, o problema dele está preso por caso de terra (...) só em Dourados sabe (...) aconteceu divisa de lote (...). Então foi questão de terra. Só que ele não fala quase português. Então, essa questão da tradução mesmo (...), do linguismo, tem necessidade de lá dentro, alguém ou algum advogado, especialista ou outro alguém (CTI, 2008, p. 29-30).

Entre as inúmeras barreiras, Pacheco e Vergílio (2006) destacam que, em muitos casos, o indígena não possui sequer o conhecimento da língua portuguesa. Muitos não sabem e não podem se expressar no idioma oficial de nosso país. Os guarani kaiowá são falantes nativos da língua guarani e o português se afigura como uma segunda língua completamente distinta para eles.

Os linguistas costumam apontar um conjunto amplo de competências comunicativas que tornam um falante proficiente no uso de determinada língua, como: competência gramatical; competência sociolinguística; competência discursiva; competência internacional (Ferreira Lima, 2007).

O outro obstáculo encontrado pelo detento indígena é a dificuldade de compreender os trâmites legais. Isso pode ser confirmado com o depoimento de um detento, um índio kaiowá, que, sem dúvida, esclarece o que vem acontecendo:

Eu não acho justo, porque, se fosse feito alguma coisa nesse [trecho inaudível] (...), eu não estaria esquentando, mas o problema é que eu estou aqui só por causa da quebra, que eu quebrei a intimação. Manda a intimação lá e ninguém entrega, então eu não vim aqui pra assinar esse 
documento [trecho inaudível], que foi mandado lá. É por isso que eu estou aqui, eu não caía, se eu tivesse assinado o documento, a intimação (CTI, 2008, p. 30).

Nesse exemplo, nota-se que o indígena apresenta uma certa noção da língua portuguesa, mas esbarra na formalidade da lei. Segundo Bourdieu (1989), o mundo social é estruturado e o modelo existente estrutura os modos de relação pessoa-pessoa e instituição-pessoa. Isso significa que todos têm poder e o exercem de alguma forma, porém, a distribuição do poder é algo socialmente dado, de modo que a posição social, a posição de classe e o prestígio gozado, não apenas conferem poder a um indivíduo, mas também sinalizam para sua existência. A distribuição desigual de poder, moldadas pela estruturação do mundo social, gera assimetrias entre as pessoas, que tornam a interação entre elas igualmente assimétricas.

As interações entre pessoas com relações simétricas de poder costumam ser mais tranquilas e livres de grandes expectativas. Estamos nos referindo à relação entre iguais; as relações assimétricas, por seu turno, comumente são permeadas por ansiedade, deferência e medo. A assimetria pode levar a um "travamento" na comunicação, caso não se tomem os devidos cuidados e não se atente para a importância de diminuir as distâncias sociais, simbólicas, de classe, de status. que separam os interlocutores.

Todos esses fatores têm efeito sobre a comunicação. É necessário fazer com que a competência sociolinguística de um falante se revele como uma forma de diminuir as distâncias entre os interlocutores, usando termos e vocabulário compatíveis com a diferença, de modo a não exacerbar as assimetrias. Essas observações são importantes para os operadores do direito que transitam por essa seara. Um juiz ou um advogado que se porte, por exemplo, como um algoz inquisidor, sem a devida sensibilidade, corre o risco de "travar" o diálogo (Ferreira de Lima, 2007).

Para finalizar o rol de exemplos, apontamos outro problema encontrado pelo indígena: o processo discriminatório arraigado nos mais diferentes compartimentos do Poder Público. De acordo com os relatos de um detento indígena, isso ocorre mais na cadeia, por causa dos funcionários, ou se mostra quando a justiça é mais rigorosa quando se trata de réu indígena, como se fosse crime ser indígena, "ser diferente". Vejamos o relato de um índio kaiowá, chefe do Posto Indígena de Dourados:

É, por exemplo, esse povo quer que vá índio preso mesmo. Olha na cara da gente assim e já tem que ir preso. Não tem esse negócio de "não". Então qualquer coisa, xadrez mesmo, não tem perdão. Se a gente não tem advogado vai mesmo [trecho inaudível] e tem um advogado lá, que na hora, lá, é na hora do júri tem aquele negócio de advogado lá que vem na hora, acompanha (CTI, 2008, p. 22). 
Atente-se para o este trecho do depoimento de um indígena kaiowá, preso na cadeia pública: “... muita pessoa [sic] que não foi condenado ainda, já tá [sic] trabalhando. Só que não é índio não. Índio é mais jogado, mais jogado que aqueles” (CTI, 2008, grifo nosso). Entre as inúmeras barreiras encontradas pelo indígena ao litigar na justiça, crê-se que uma das principais reside na questão da comunicação através da língua portuguesa.

Conforme já apontado, sabe-se que muitos dispositivos encontrados no Estatuto do Índio, ainda em vigor, estão obsoletos frente à Constituição Federal de 1988 e aos Tratados e Convenções Internacionais firmados pelo Brasil em matéria de direitos humanos. Como indica o artigo 56; § único, Lei 6001/73, reforçado pelo artigo 10 da Convenção 169 da OIT: "Dever-se-á dar preferência a tipos de punição outros que o encarceramento", instituindo assim um regime especial de cumprimento de pena. Ademais, a própria Constituição Federal, em seu artigo 231. obriga o reconhecimento da organização social, costumes línguas, crenças e tradições dos índios (Brasil, 1988). Não obstante, observa-se que a prática não atinge os patamares desejados pelo legislador.

Não se pode olvidar que somado ao artigo 231 da Constituição o artigo $8^{\circ}$ da Convenção 169 da OIT é claro ao indicar que ao ser aplicada a legislação nacional aos povos interessados "deverão ser levados nas devidas considerações seus costumes ou seu direito consuetudinário” (OIT, 1969, grifo nosso).

Como já indicado nossa intenção não é lançar uma análise exaustiva sobre a técnica legislativa ou sobre às normas específicas que não são consideradas e/ou aplicadas pelo Poder Judiciário do Estado de Mato Grosso do Sul. Entretanto, frisamos que o direito a um direito diferenciado, que contemple as especificidades dos povos indígenas naquele Estado da Federação está esquecido, e sua aplicação está muito aquém do que julgamos deveria estar.

\section{POR UM DIREITO À DIFERENÇA: A APLICAÇÃO DO DIREITO CONSUETUDINÁRIO AOS POVOS INDÍGENAS}

"Conceitos muitos diferentes, ainda que semelhantes aos nossos, podem nos parecer muito estranhos, como desvios do comum numa direção insólita. E outros possuem conceitos que se cruzam com os nossos. Eu quero dizer que uma educação muito diferente da nossa pode também servir de base a conceitos bastante diferentes.” Ludwig Wittgenstein

Antes da intervenção do direito estatal nas comunidades indígenas, estas eram regidas por um direito interno baseado nos costumes e tradições, o direito consuetudinário indígena, ou como alguns doutrinadores preferem chamar: direito indígena. É 
importante ressaltar, e gostaríamos de insistir, que direito indígena e direito indigenista não são sinônimos; isso em geral causa confusão, inclusive no meio jurídico e acadêmico. ${ }^{16} \mathrm{O}$ primeiro constitui o direito costumeiro ou direito consuetudinário, enquanto que o direito indigenista consiste em normas legislativas feitas pelo Estado e impostas aos indígenas.

Com o advento da Constituição Federal de 1988, o direito costumeiro passou a ser reconhecido, mas isso aparecia de forma tímida. Esse direito ressurgiu -, com certo vigor, nos teores de alguns documentos -, relacionado ao direito indigenista, principalmente na Convenção 169 da OIT, artigos $8^{\circ}$ e $10^{\circ} .{ }^{17}$

O direito consuetudinário, embora não reconhecido pelo direito positivo, e também não escrito em códigos e legislações, é respeitado pelos costumes, e constitui elemento básico da identidade étnica de um povo. Sendo assim, está sujeito à tutela Constitucional, como se pode ver a seguir:

Embora controvertido, o conceito de consuetudinário normalmente relaciona-se a um conjunto de normas legais tradicionais, não escritas nem codificadas, distintas daquelas do direito positivo vigente em um determinado estado. Sua principal característica é a existência de um corpo de regras e costumes delimitado, reconhecidos e compartilhados por uma dada coletividade, o qual difere e contrasta com o direito positivo vigente. Esse último emana de autoridade constituída e a sua aplicação está nas mãos daquela autoridade; aquele vigora e opera apesar da existência do estado (leitão, 1993, p. 229).

A detenção, o encarceramento, implica perder os vínculos com a família e o convívio comunitário, um grave problema para um povo que tem os valores dessas funções sociais ligadas sobremaneira à sua própria noção de pessoa e pertencimento. Percebemos que a maioria dos presos entrevistados nos presídios não recebiam visitas, e por se ressentirem disso caíam em profunda depressão. O distanciamento das aldeias e as exigências do próprio presídio dificultam as visitas. Estes segregados da comunidade vão gradativamente enfraquecendo seus vínculos sociais, ocasionando até a dispersão de suas famílias.

Percebe-se que a necessidade de reconhecimento do direito indígena permeia a realidade dos detentos indígenas:

Eu acho que este daí tem que avançar (...) é, inclusive com os agentes carcerários, indígena que fala o idioma pra poder também repassar pra própria família (...). Fazer essa interlocução lá dentro (...) porque parente está assim, ele está precisando disso, ele está sentindo assim (...). Ele teria uma melhor, vamos dizer assim, essa re-socialização [sic] seria acho que 
mais válido do que ele se [sic] preso aí no meio de preso comum, numa penitenciária grande como no caso do Harry Amorim (CTI, 2008, p. 33).

\section{I ObSTÁCULOS À APLICAÇÃo DO DIREITO CONSUETUDINÁRIO INDÍGENA no Âmbito do Direito Penal}

Diante da argumentação de que o indígena teria, de forma imperiosa, que deixar de ser índio, e abrir mão de sua identidade como indígena, para adotar costumes que não lhe pertencem, é importante frisar que a Constituição Federal de 1988 desconsiderou conceitos trazidos pela Lei 6001/73, O Estatuto do Índio. Tais conceitos se referiam à incorporação do indígena à sociedade nacional. Infelizmente, o anacrônico, mas ainda em vigor Estatuto do Índio, ainda é o principal e primeiro cânone utilizado e mencionado por muitos operadores do direito não informados, quando se deparam com alguma questão de direito indigenista.

Até a Constituição de 1988, era comum, tanto no aspecto da legislação quanto no âmbito social, utilizar-se um pensamento integracionista para com o indígena. Entre outras premissas, esse pensamento apontava que o indígena deveria ser integrado à sociedade envolvente. Os conceitos integracionistas não mais cabem no atual ordenamento jurídico nacional, pois,

... aspecto que às vezes remete à consideração equivocada de alguns, consiste na suposta necessidade de investigar se o beneficiário deste tratamento normativo seria índio integrado, em vias de integração ou isolado, ou mesmo se seria aculturado ou não. Essas categorias com a promulgação da Constituição em 5 de outubro de 1988 deixam de existir. Com o dispositivo no art. 231 da CF, vigora o principio Constitucional do respeito à diversidade étnica cultural; não há, portanto distinção juridicamente válida e relevante em relação aos índios. Ou seja, pouco importa que um índio ou uma comunidade mantenham contato permanente, recente ou antigo ou que não mantenham qualquer contato com a sociedade indígena (Guimarães, 2002).

Atualmente grande parte de operadores do direito tem conservado a visão integracionista do indígena presente no artigo 56 do Estatuto do Índio, que dispõe: "no caso de condenação de índio por infração penal, a pena deverá ser atenuada e na sua aplicação o juiz atenderá ao grau de integração silvícola” (Brasil, 1971, grifo nosso). O próprio termo "silvícola” está fora de uso pelo jargão antropológico especializado.

Infelizmente, quando se trata de jurisprudência ${ }^{18}$ em questão indígena, algumas decisões de Tribunais, a respeito da imputabilidade dos indígenas, ainda persistem na óptica integracionista. Em algumas decisões estes eram considerados inadaptados ou até mesmo comparados a pessoas de desenvolvimento mental incompleto ou retardado, como previsto no artigo 26 do Código Penal. ${ }^{19}$ 
Diante das estimativas de que o índio era portador de desenvolvimento mental incompleto, Zaffaroni e Pierangeli criticaram severamente esse pensamento:

De maneira alguma pode se sustentar que o silvícola, ou aquele que comporte de regras de qualquer outro grupo cultural diferenciado, seja inimputável, ou uma pessoa com uma imputabilidade diminuída, como se sustenta com frequência. Trata-se de pessoas que podem ser, ou não ser inimputáveis, mas pelas mesmas razões que podemos nós também o ser, e não por pertencer a um grupo culturalmente diferenciado. A psiquiatria ideológica - biologista e racista - já produziu estragos em demasia para continuar buscando suas soluções aberrantes (Zaffaroni e Pierangeli, 2004, p. 649).

Em grande parte das decisões, a óptica integracionista ainda tem predominado, fato que se deve ao atendimento às cogitações do senso comum, esquecida a necessária aplicação do regime jurídico indígena derivado de suas tradições, crenças, costumes, organização social e direitos originários que a Constituição reconheceu (Castilho e Paranhos, 2003).

Esse quadro permite afirmar, portanto, que os objetos jurídicos tutelados pela Constituição Federal de 1988 são inteiramente peculiares, pois que, além de abranger os objetos jurídicos do direito não indígena na forma constitucional vigente, também haverá de atender às regras ditadas pela tradição, cultura, organização e valores dos indígenas, que podem e devem ser igualmente protegidos, civil e penalmente, até mesmo quando não explicitamente previstos na legislação ordinária do País, já que a Constituição reconheceu as regras indígenas e, portanto, os valores respectivos (inclusive jurídicos) cuja violação justifica sanção.

Em outras palavras, se a Constituição aceita e reconhece os direitos e interesses indígenas gerados pela tradição, há de tê-los igualmente incluídos no rol dos interesses e direitos do direito ordinário brasileiro, garantindo-lhes, juntamente com esses últimos, idêntica proteção (Castilho e Paranhos, 2003).

A partir do reconhecimento à diversidade cultural do indígena, merece destaque a questão do laudo antropológico. Modifica-se a razão de ser do laudo antropológico no processo penal: este não serve mais para saber se o índio é inimputável ou semi-inimputável em razão do grau de internalização dos valores do homem não índio, mas para explicar como o fato que levou ao processo penal é entendido na sua cultura especificamente (Guimarães, 2002). Contudo isso não significa que:

... haya una existencia de un Derecho Penal indígena en estado puro, no sólo porque la imposición de un derecho penal de corte occidental europeo durante siglos relegó ése ordenamiento consuetudinario a un segundo plano, sino porque las características del mismo varían de agrupación en agrupación, no empecé lo cual se 
pueden mostrar unas directrices generales que son comunes a los diversos núcleos de población, especialmente en Bolivia, Perú, Ecuador, Colombia, Méjico, Nicaragua, Guatemala, etc., entre otros (Jiménez, 2000, p. 28).

Ademais, com base na mudança na compreensão do reconhecimento de diferenças culturais, torna-se imprescindível a perícia antropológica para identificar as normas culturais relacionadas com o delito supostamente contido e não para discutir a sua inimputabilidade. Apesar do reconhecimento do direito consuetudinário, há uma dificuldade em sua aplicação, pelo fato de aquele não ser compatível com o sistema legal vigente: o problema encontrado aqui é que o simples reconhecimento de um direito consuetudinário implica a necessidade de compatibilizá-lo, na prática, com o direito positivo vigente. E no entendimento de Venne "se os sistemas legais têm raízes e necessidades diferentes”, há poucas chances de serem compatíveis entre si (Leitão, 1993, p. 230).

Ainda com base em Leitão (1993), nos seus informes sobre a violação dos direitos dos índios em diversos países, a ONU concluiu, ante a coexistência de uma norma jurídica nacional e várias outras de natureza consuetudinária que regem a vida das diversas sociedades indígenas existentes em um determinado território, ser necessário o respeito aos sistemas legais indígenas e a admissão, por parte dos Estados, da existência de um pluralismo jurídico sem preeminências injustificadas das partes do sistema jurídico nacional. No entanto, a maior parte dos Estados resiste e se contrapõe ao reconhecimento desses sistemas.

Sendo assim, é imperioso criar, por meio da legislação ordinária, formas de coexistência entre o direito interno indígena e o direito positivo nacional, sem preeminências injustificadas, que seriam juridicamente falsas, moralmente condenáveis e socialmente injustas. Não se pode permitir que o espírito que regeu a Constituinte de 1988 seja deturpado ou sofra retrocesso, é necessário que se dê a devida consideração para o tema, só assim os povos indígenas continuarão existindo de forma completa.

Aqui reside a importância de estudarmos o direito vinculado a outras disciplinas, dentre elas a antropologia, pois esta pode ser uma importante ferramenta para entender a articulação entre o local e o global. De um lado temos a perspectiva antropológica que busca saber como o particular pode nos ensinar sobre o universal, uma vez que o "mundo do direito" em alguns casos parte de premissa contrária, qual seja, aplica o universal sobre o que é particular, com base numa nova Antropologia Jurídica Indigenista.

\subsection{Aplicação de Penas de ACORdo COM O DiREITO CONSUETUdinário INTERNO DAS COMUNIDADES INDÍGENAS, EM CASO DE CRIMES ENVOLVENDO MEMBROS DO MESMO GRUPO ÉTNICO E/OU COMUNIDADE}

Observa-se que muitas vezes os indígenas, são detidos por crimes de menor potencial ofensivo, onde as partes, em sua maioria, são integrantes da própria comunidade. 
Essas situações, antes da intervenção estatal, eram resolvidas internamente, descartando-se a possibilidade do encarceramento. Esse fato é recordado por uma liderança indígena da época em que o capitão Ireno, grande liderança kaiowá de Dourados, resolvia os conflitos dentro das próprias comunidades:

... ele dava essa atenção com esse tratamento, que muitas coisas ele mesmo resolvia. Ele, dependendo, se fosse briga familiar, ele dava aí uma tarefa, alguma coisa (...); o cara bater na mulher, é sempre produzindo coisa pra a comunidade de novo (...), tirava aquela troca né, e hoje já tá (...). [Hoje], qualquer coisa mandam para delegacia, ou vai lá para delegacia de mulheres, por fim fica só uma andança (...), aí fica não sei, e de repente reincide de novo, fica reincidente (índio kaiowá, chefe de Posto) (CTI, 2008, p. 21).

Note-se que os próprios indígenas ressentem-se da falta de um direito diferenciado, que respeite a diversidade. Conforme o depoimento supra, a pena imposta pelo direito positivo não atinge o objetivo desejado.

Há muito já se tem discutido sobre ser a prática do encarceramento um meio adequado para a "re-socialização" entre os não indígenas. Atente-se para o fato de esse encarceramento ser realizado com indígenas, povos que por sua estrutura social têm outras regras e sanções.

O encarceramento tem servido muito mais como forma de exclusão daquele indivíduo da sua própria comunidade do que de re-socialização. Essa prática acaba trazendo muitos transtornos para a família e para aquele que foi detido, uma vez que a não interação de culturas promove a incompreensão dos reais objetivos.

Segundo depoimento colhido junto ao delegado de polícia de um município da grande Dourados, o encarceramento é uma forma de forçar o indígena a conviver com os vícios e obrigá-lo à prática de condutas delituosas que, até então, não faziam parte do seu modo de vida, no âmbito de sua comunidade de origem.

Conforme Dallari (2001), conviver com os vícios e a violência dos padrões capitalistas de interação humana é condenar o indígena à degradação física, psíquica e moral, apressando a sua morte, tanto física, quanto espiritual ou cultural. O indígena, ao ser encarcerado por um determinado tempo, acaba tendo sua cultura vilipendiada, fato que é contrário à proteção que lhe dá a Constituição Federal de 1988 e demais Tratados Internacionais dos quais o Brasil é signatário.

Sabe-se que os indígenas têm modos de vida peculiares e não têm muito envolvimento com os hábitos da sociedade que os cercam. A questão continua: como re-socializar um indivíduo que não compartilha os hábitos da sociedade envolvente, por pertencer a uma cultura diversa dessa sociedade; [indivíduos] que durante mais de três quartos de século foram obrigados a se integrar a esse mesmo mainstream que lhe condena por ser diferente? Por esta razão, entende-se inviável esse modelo de 
punição, o encarceramento. Ao utilizá-lo, está-se destruindo a cultura indígena, em conformidade com a linha de pensamento e preocupação contidos na Declaração das Nações Unidas sobre os Direitos dos Povos Indígenas (art. $8^{\circ}$, parágrafos 1 e $2 .{ }^{20}$

A preocupação de revitalizar e promover o reconhecimento, por parte dos Estados, do direito interno das comunidades indígenas, o projeto de Declaração da Organização dos Estados Americanos (OEA) sobre os Direitos dos Povos Indígenas (OEA-DDPPII), em seu artigo XXI; 1, 2, ${ }^{21}$ comunga o mesmo entendimento.

Os dispositivos internacionais surgem com o intuito de zelar pelo indígena, cabendo ao signatário de várias Convenções e Pactos Internacionais a observância desses dispositivos jurídicos. Pelas razões expostas, não procede a afirmação de que somente o direito positivo é eficaz para a resolução de conflitos no seio das comunidades. Erigir o direito positivo à supremacia, em detrimento das razões culturais, é negar a existência da diversidade.

A Convenção 169 da OIT, em seu artigo 10 , dispõe especificamente sobre os indígenas apenados: "Quando sanções penais sejam impostas pela legislação geral a membros dos povos mencionados, deverão ser levadas em conta as suas características econômicas, sociais e culturais"; e "Dever-se-á dar preferência a tipos de punição outros que o encarceramento".

Vários autores latino-americanos (Fajardo, 1999; Gomez, 2000, e outros), enfatizam os mecanismos para o respeito de atos jurídicos indígenas, aduzindo que as normas para uma coordenação entre os sistemas jurídicos deveriam estabelecer instrumentos que garantissem o reconhecimento legal dos atos jurídicos realizados dentro do direito indígena (união conjugal, nomes, filiação, formas de contratos, etc.), sem querer estabelecer novos requisitos que na prática significam o desconhecimento do que já fora pactuado entre os povos indígenas.

Diante da história da expropriação a que foram submetidos os povos indígenas, a qual foi fator debilitador de seus direitos, urge o estabelecimento de políticas públicas para o fortalecimento da cultura indígena, de suas autoridades, instituições e procedimentos consensuais e participativos. Essas políticas devem ser pensadas com a participação dos indígenas e com um diálogo intercultural amplo.

\section{CONSIDERAÇÕES FINAIS}

Com a crescente demanda dos povos indígenas pela afirmação de sua identidade e a busca pelos seus direitos, entende-se que o direito positivo, tal qual está posto, em especial o Direito Penal, não pode escusar-se a tratar destes problemas. É premente que o legislador encare essa realidade à luz dos fatos culturais da real pluralidade entre as sociedades conviventes.

Primeiro, porque os povos indígenas hoje se fizeram visíveis, estão presentes e querem ser identificados como indígenas. Segundo, porque o direito positivo, tal qual 
vem sendo aplicado, promoveu mais injustiça do que justiça. Terceiro, porque a aprovação da Constituição Federal de 1988 consagrou um capítulo próprio para os indígenas, especificamente o artigo 231, entre outros que tratam da proteção ou respeito à diversidade cultural. Essa é uma medida tomada pelo Constituinte, no sentido de executar outro Princípio Constitucional, o da igualdade: "tratar de forma igual os iguais e de forma desigual os desiguais na medida de sua desigualdade” (Santos, 1995).

Acrescente-se que o direito indígena deve ser repensado em função das Convenções e Acordos Internacionais, assim como a partir da forma de aplicar sanções quando estas disserem respeito a atos ilícitos praticados por indígenas.

O sujeito indígena, ao enfrentar a justiça, deve ter assegurado um tratamento diferenciado que leve em consideração sua cultura, sua forma de vida e, sobretudo, a necessidade de ele compreender e se fazer compreender.

Por certo, passados mais de vinte anos da promulgação da Constituição de 1988, não se coloca mais em dúvida que o Estado nacional é pluriétnico e multicultural, e que todo o direito, em sua elaboração e aplicação, tem esse marco como referência inafastável.

A não aplicação do direito ao tratamento diferenciado desrespeita o preceito Constitucional, situação muito comum nos interrogatórios de indígenas, nos quais a maioria não consegue dizer uma só palavra, e, ficando calados, são interpretados como no provérbio popular. "quem cala consente".

Além de desrespeitar os preceitos constitucionais, viola-se também os Tratados e Convenções Internacionais, assim como a cultura interna da comunidade, que, na maioria das vezes, possui seus próprios sistemas jurídicos, que não são levados em consideração por parte do Estado.

Urge que novos conceitos e novas concepções sejam amplamente divulgados, iniciando-se pelos cursos de Direito, que, em sua maioria, ainda apresentam uma visão positivista, alheia à realidade, instruindo o futuro operador do direito como um mero aplicador do cânone jurídico. Isso não tem mais lugar na sociedade em que se vive atualmente. Deve-se levar em consideração que as novas concepções que estão em consonância tanto com o direito interno quanto com o direito internacional devem fazer parte do cotidiano do sistema Judiciário, para que ocorra realmente uma sociedade mais justa, e a democracia possa de fato fazer parte do cotidiano das pessoas, incluindo, índios e não índios.

Certo é que, apesar dos vários mecanismos de proteção aos direitos indígenas, muito está por fazer. Dentre outras providências, é preciso estabelecer princípios, tais como o da dignidade das culturas, para superar o conceito de minorias. Também, estabelecer um diálogo intercultural com mecanismos de articulação e consulta, bem como uma distribuição do poder de definição em espaços normativos, jurisdicionais e de políticas públicas, além de estabelecer garantias institucionais e processuais que viabilizem a equidade com reconhecimento do direito a diferença cultural. 
Este trabalho teve como escopo, lançar um novo olhar sobre o direito tal qual está positivado, em especial sobre o direito penal, uma vez que, apesar de existirem múltiplos textos, pactos, protocolos de caráter nacional e internacional de proteção a direitos indígenas, observa-se que as violações a esses direitos são constantes.

: ARTIGO APROVADO (08/12/2011) : RECEBIDO EM 13/07/2011

\section{NOTAS}

1 Fundação Nacional do Índio (Funai). "Cabe esclarecer que esse dado populacional considera tão somente aqueles indígenas que vivem em aldeias, havendo estimativas de que há entre 100 e 190 mil vivendo fora das terras indígenas, inclusive em áreas urbanas. Há também 63 referências de índios ainda não contatados, além de existirem grupos que estão requerendo o reconhecimento de sua condição indígena junto ao órgão federal indigenista.”. Disponível em: www.funai.gov.br/. Acesso em: 21 nov. 2011.

2 Especificamente sobre a capacidade indígena o Código Civil em vigor traz em seu art. $4^{\circ}$, $\S$ único, que: “a capacidade civil dos índios será regulada por lei especial” (Brasil, 2002) não fazendo qualquer referência à tutela.

3 A propósito, vide Les droits des peuples autochtones et tribaux dans la pratique: un guide sur la Convention n. 169 de l'OIT, Genebra, OIT, 2009.

4 A prática de usar o direito indígena ou consuetudinário, desde que não violem os direitos humanos e o direito interno do País, não será discutida neste artigo. Apenas lançaremos um olhar sobre o fio condutor, que é o direito indígena aplicado aos povos indígenas. Tem-se em conta que, até os dias atuais, a Corte Interamericana de Direitos Humanos não foi confrontada ao caso de uma eventual violação dos direitos humanos por práticas culturais, como, por exemplo, algumas penas utilizadas, a questão do infanticídio, castigos corporais, mutilações, dentre outras.

5 A esse respeito vide "Estando, portanto, eliminada a perspectiva incorporativista, o objetivo final da tutela aos índios deixou de existir. Dessa forma, opera-se evidente incompatibilidade entre a legislação preexistente e a constituição superveniente. A dimensão protetiva da tutela foi substituída pela determinação constitucional atribuída à União Federal para proteger os bens indígenas, no intuito de que sejam respeitados” (Guimarães, 2005, p.14).

6 Vide $6^{\text {a }}$ CÂMARA DE COORDENAÇÃO E REVISÃO DO MINISTÉRIO PÚBLICO FEDERAL. Processo CC n. 33303-TO (2001/0125759-9) APELAÇÃO CRIMINAL - TRÁFICO DE ENTORPECENTES CRIME PRATICADO POR ÍNDIO - COMPETÊNCIA - JUSTIÇA FEDERAL. "Em face da hodierna ordem constitucional, é de se reconhecer a competência da Justiça Federal para processar e julgar qualquer crime onde figure como autor ou vítima indígena. Disponível em: http://ccr6.pgr.mpf.gov.br/atuacao-do-mpf/acao-civilpubliva/docs_recursos_judiciais/RE_Dra_\%20Ela_Wiecko_2002.pdf. Acesso em: 12 nov. 2011.

7 “... o direito indigenista é o ramo do direito positivo vigente na sociedade nacional que tem por função regulamentar a convivência entre as sociedades indígenas e esta mesma sociedade nacional. O direito indigenista, 
portanto, é um direito ocidental ('branco') criado para reger as relações dos indígenas com a sociedade envolvente" (Antunes, 1998, p. 136).

8 “... conjunto de normas e procedimentos, internos a uma comunidade indígena, que seja capaz de regular as relações no âmbito desta mesma comunidade e que para sua constituição concorram, em maioria, os elementos típicos do modo de vida peculiar e característico dos próprios povos aborígines” (Antunes, 1998, p. 136).

9 Sobre esse tema literário, vide a obra Galvão, Walnice Nogueira. Indianismo revisitado. Cadernos de Opinião, n. 13, ago./set. 1979.

10 Seguindo o fio histórico da evolução da defesa dos direitos dos povos indígenas, com o advento da Convenção n. 169 da OIT, em 1989, o apoio ao integralismo dos padrões anteriores encontrados na Convenção n. 107 é suprimido, sobre essa discussão vide: BRÖLMANN e ZIECK (1993, p. 203). Entre os fatores justificando a revisão da Convenção n. 107, os autores citam a linguagem paternalista do tratado e o objetivo desatualizado de uma integração progressiva.

11 Isso se verifica logo, desde a definição das populações indígenas onde são consideradas como tais aquelas “cujas condições sociais e econômicas correspondem a um estágio menos adiantado que o atingido pelos outros setores da comunidade nacional e que sejam regidas, total ou parcialmente, por costumes e tradições que lhes sejam peculiares ou por uma legislação especial" (art. $\left.1^{\circ}, \S 1^{\circ}, a\right)$ da Convenção n.107 da OIT.

12 Os votos contra a Declaração vieram de quatro países com uma importante minoria indígena e, coincidentemente ou não, de extrato colonizador anglo-saxão: Austrália, Canadá, Nova Zelândia e Estados Unidos, que negam a existência de um direito ilimitado dos povos indígenas à autodeterminação. Na América do Sul a Colômbia foi o único país que se absteve enquanto o Brasil, apesar de ter sido em vários momentos contra os aspectos da Declaração, trazendo objeções, acabou por votar a favor.

13 No Mato Grosso do Sul suicídios na adolescência, alcoolismo, assassinatos de lideranças, exploração de mão de obra são fatos sociais que há pelo menos duas décadas são expostos pela mídia sobre os Kaiowá e Guarani no Mato Grosso do Sul, uma população de 43 mil índios. Na raiz desse drama social não cansam de enfatizar lideranças indígenas e especialistas, encontra-se a questão das terras Kaiowá-Guarani. Segundo Gilberto Azanha, Coordenador Geral do CTI, “Até meados da década de 1980, as terras disponíveis pelo Estado brasileiro para aquela população (20 mil à época, cerca de 2.500 famílias) perfaziam um total de 18.124 hectares, ou seja, cerca de sete hectares por família - quando o módulo mínimo do Incra era de 50 hectares. Passadas duas décadas, este quadro só se agravou. O Estado brasileiro reconheceu, nos anos 1990, mais 21.275 hectares que estão na posse efetiva dos Kaiowá e Guarani no Mato Grosso do Sul, mais que duplicando a área disponível. Porém a população também mais que duplicou, anulando os efeitos positivos daquele acréscimo. Segundo dados da Funasa (2007), as reservas demarcadas pelo Serviço de Proteção aos Índios (SPI) nos anos 1920 seguem abrigando 79\% (33.306) da população Kaiowá e Guarani, sendo que 21.543 indígenas, ou 51\% desse total, estão concentrados em apenas três Terras Indígenas - Dourados, Amambai e Caarapó - que somam 9.498 hectares de terra. Somente nessas três Reservas Indígenas são 3.000 famílias que dispõem tão somente de três hectares para, literalmente, sobreviverem. Todos os especialistas da questão Kaiowá-Guarani são unânimes em apontar a causa (a falta de terras) e a solução (reconhecer suas terras tradicionais) para que esta parcela da população brasileira - com toda certeza a mais sofrida e vulnerável do país - possa se reorganizar e enfim obter um pouco de paz e almejar a dignidade que merecem” (CTI, 2008).

14 É importante ressaltar que, com o escopo da efetivação dos Direitos Indígenas, foi possível ocorrer um acompanhamento jurídico mais eficaz aos indígenas do município de Dourados, com a criação do Projeto "Núcleo de Cidadania Dorvalino Rocha”, que é desenvolvido na cidade de Dourados, MS, que possui a finalidade de prestar amparo jurídico aos indígenas da região da Grande Dourados. O Projeto Dorvalino Rocha é fruto de um convênio firmado entre a então Secretaria de Direitos Humanos da Presidência da República e o Centro de Defesa da Cidadania e dos Direitos Humanos Marçal de Souza Tupã-i (CDDH).

15 A situação se agrava ao se verificar que a Funai em Dourados não possui a estrutura básica (jurídica) para atender à população indígena na região da Grande Dourados, que é a mais numerosa do Mato Grosso do Sul, contando com aproximadamente 20.000 indivíduos (CTI, 2008).

16 vide Antunes (1998); Santos Filho (2005); Barreto (2003). 
17 "Art. $8^{\circ}$ - Ao aplicar a legislação nacional os povos interessados deverão ser levados na devida consideração seus costumes ou seu direito consuetudinário [...] Art. $10^{\circ}$ Quando as sanções penais sejam impostas pela legislação geral a membros dos povos mencionados, deverão ser levadas em conta as suas características econômicas, sociais e culturais."

18 "A eventual inimputabilidade de um silvícola somente será reconhecida se, mediante perícia, ficar demonstrado que o réu possui desenvolvimento mental incompleto ou retardado" (TACRIM-SP-AC-Rel. Heitor Prado-BJM 67/10 e RJD 2/98). "Na cláusula de desenvolvimento mental incompleto ou retardado, prevista no art. 22 do CP (atual 26), pode situar-se o silvícola, desde que fique demonstrada sua inadaptação à vida do meio civilizado" (STF- HC- Rel. Djaci Falcão-RDP/2/110). "O eminente Prof. Anibal Bruno, cuidando dos portadores de deficiência mental incompleta ou retardada, ministra a seguinte lição: “... a essas categorias de insuficientes devem ser assimilados os silvícolas não ajustáveis ao nível cultural da vida civilizada. Não há nada aí de patológico, ou teratológico, é claro, mas a ausência de adaptação à vida social do nosso nível, as normas complexas que a regulam, e aos critérios de valores dos nossos julgamentos, além da existência de certas tonalidades dos processos psíquicos desses indivíduos e de certos complexos afetivos, que os dirigem e os opõe em condição de incapacidade de entendimento e orientação volitiva na qualidade e grau exigido pelo Código" (Direito Penal, 2. ed., vol.I, t. II/137)"(TJSC-HC-Rel. Marcilio Medeiros-RT).

19 "Inimputáveis: Art. 26. É isento de pena o agente que, por doença mental ou desenvolvimento mental incompleto ou retardado, era, ao tempo da ação ou da omissão, inteiramente incapaz de entender o caráter ilícito do fato ou de determinar-se de acordo com esse entendimento.”

20 "Art. $8^{\circ}$. 1. Os povos e as pessoas indígenas têm o direito de não sofrer da assimilação forçosa ou a destruição da sua cultura. 2. Os Estados estabelecerão mecanismos efetivos para a prevenção e o ressarcimento de: a) Todo o ato que tenha por objeto ou consequência privá-los de sua integridade como povos distintos ou de seus valores culturais, ou sua identidade étnica. d) Toda forma de assimilação e integração forçada.”

21 1- Los Estados reconocerán la [competencia] de las autoridades de los pueblos indígenas para ejercer [funciones jurisdiccionales] dentro de su ámbito territorial de conformidad con sus propias normas, institucionales y procedimientos. Los pueblos indígenas tienen el derecho a mantener [controlar] y reforzar sus sistemas jurídicos para el tratamiento de los asuntos internos que afectan sus derechos e interés, y de aplicarlos según sus propias normas y procedimientos. 2- El derecho y los sistemas jurídicos indígenas deben ser reconocidos y respetados por la orden jurídico-nacional [e internacional].

\section{REFERÊNCIAS BIBLIOGRÁFICAS}

AGÊNCIA BRASIL. Reserva de Dourados tem maior concentração de índios do país. Disponível em: www.agenciabrasil.gov.br/noticias/2007/12/19/ materia.2007-12-19.0041900324/view. Acesso em: 20 set. 2008.

ANTUNES, Paulo de Bessa. Ação Civil Pública, meio ambiente e terras indígenas. Rio de Janeiro: Lúmem Júris, 1998.

AZEVEDO, Marta. Censos Demográficos e os "índios": dificuldades para reconhecere contar. In: Carlos Alberto Ricardo. (Ed.) Povos índigenas no Brasil - 1996/2000. São Paulo: Instituto Socioambiental, 2000. BARBOSA, Marco Antonio. Autodeterminação: Direito à diferença. São Paulo: Plêiade/ Fapesp, 2001.

BARRETO, Helder Girão. Direitos Indígenas. Vetores constitucionais. Curitiba: Juruá, 2003.

BARTH, Fredrik. (Org.). Los grupos étnicos y sus fronteras. Cidade do México: Fondo de Cultura Económica, 2000.

BOURDIEU, Pierre. O poder simbólico. Tradução de Fernando Tomaz. 6. ed. Rio de Janeiro: Bertrand Brasil, 2003.

BRAND, Antônio. Os Kaiowá/Guarani no Mato Grosso do Sul e o processo de confinamento - a “entrada de nossos contrários”. In: Conselho Indigenista Missionário; Comissão Pró-Índio; Ministério Público Federal. (Org.) Conflitos de direitos sobre as terras Guarani Kaiowá no estado do Mato Grosso do Sul. São Paulo: Palas Athena, 2001, p. 93-131. 
BRASIL. Decreto-lei n. 2.848, 7 de., 1940. Presidência da República, Casa Civil. Subchefia para Assuntos Jurídicos. Código Penal. Disponível em: www.planalto.gov.br/ccivil_03/decreto-lei/del2848.htm. Acesso em: 11 mai. 2011.

BRASIL. Constituição da República Federativa do Brasil de 1988. Presidência da República, Casa Civil. Subchefia para Assuntos Jurídicos. Disponível em: www.planalto.gov.br/ccivil_03/constituicao/ constitui\%C3\%A7ao.htm. Acesso em: 11 mai. 2011.

BRASIL. Projeto de Lei 2057/1991, que cria o Estatuto das Sociedades Indígenas. Câmara dos Deputados. Disponível em: www.camara.gov.br/proposicoesWeb/fichadetramitacao?idProposicao=17569. Acesso em 19 jun. 2011.

BRASIL. Senado Federal. Subsecretaria de Informações. Decreto legislativo n. 143, 2002. Aprova o texto da Convenção n. 169 da Organização Internacional do Trabalho sobre os povos indígenas e tribais em países independentes. Disponível em: www6.senado.gov.br/legislacao/ListaPublicacoes.action?id=234865. Acesso em: 7 jul. 2011.

BRASIL. Código civil. Lei n. 10.406, 10 jan. 2002. Presidência da República, Casa Civil. Subchefia para Assuntos Jurídicos. Disponível em: www.planalto.gov.br/ccivil/leis/2002/L10406.htm. Acesso em: 20 jun. 2011.

BRÖLMANN, Catherine; ZIECK, Marjoleine, Indigenous Peoples. In: Catherine; LEFEBER, René Brölmann; Marjoleine Zieck. (Eds.) Peoples and Minorities in International Law. Dordrecht: Martinus Nijhoff Publishers, 1993.

CANÇADO TRINDADE, A. A. Tratado de Direito Internacional dos Direitos Humanos. v. 1. Porto Alegre: Sérgio Antonio Fabris Editor, 1997. 3 v.

CASTILHO, E. W. V.; PARANHOS, F. Violência na Terra Indígena Sororó. Nota Técnica, Brasília, 6 a Câmara de Coordenação e Revisão, Ministério Público Federal, 2003.

CASTILHO, M. L. V. A competência nos crimes praticados por ou contra indígenas. Disponível em: www.ajufergs.org.br/revistas/rev01/01_dr_volkmer.pdf. Acesso em 21 nov. 2011.

CENTRO DE TRABALHO INDIGENISTA (CTI). Situação dos Detentos Indígenas do Estado de Mato Grosso do Sul. Brasília, 2008.

CONSELHO INDIGENISTA MISSIONÁRIO (CIMI). Território Tradicional dos Guarani/Kaiowá no Estado do Mato Grosso do Sul. In: Conselho Indigenista Missionário; Comissão Pró-Índio; Ministério Público Federal. (Orgs.) Conflitos de direitos sobre as terras Guarani Kaiowá no estado do Mato Grosso do Sul. São Paulo: Palas Athena, 2001.

DALLARI, Dalmo de Abreu. In: Conselho Indigenista Missionário; Comissão Pró-Índio; Ministério Público Federal. (Org.) Conflitos de direitos sobre as terras Guarani Kaiowá no estado do Mato Grosso do Sul. São Paulo: Palas Athena, 2001.

DÍAZ-POLANCO, Héctor. Elogio de la Diversidad: Globalización, Multiculturalismo y Etnofagia. México: Siglo XXI, 2006.

DUPRAT, Deborah, Procuradoria da Republica em Mato Grosso do Sul : Deborah Duprat (vice-PGR): A reserva de Dourados é talvez a maior tragédia conhecida na questão indígena em todo o mundo. Disponível em: http://ccr6.pgr.mpf.gov.br/institucional/encontros/xi-encontro/entrevista-dra-deborah-questaoindigena-e-presidio-federal-em-campo-grande. Acesso em: 10 nov. 2011.

GUIMARÃES, Paulo Machado. Os efeitos da detração penal sobre os direitos dos povos indígenas. Disponível em: www.cimi.org.br/?system=news\&action=read\&id=316\&eid=262. $>$ Acesso em: 12 set. 2010.

. Curso de Extensão "Direito indigenista para acadêmicos índios de MS”. Brasília-DF, 2002.

FAJARDO, Raquel Yrigoyen. Pautas de Coordinación entre el Derecho Indígena y el Derecho Estatal. Guatemala: Fundacion Myrna Mack, 1999

FERREIRA DE LIMA, Marcos Homero. Perícia antropológica realizada para o Ministério Público do Trabalho, MPF, Procuradoria da República em Dourados, 2007.

GALVÃO, Walnice Nogueira. Indianismo revisitado. Cadernos de Opinião, n. 13, ago./set. 1979.

GOMEZ, Magdalena. Derecho indígena y constitucionalidad. In: Milka Castro. (Org.) Actas del XII Congreso Internacional de Ciências Antropológicas y Etnológicas. Comisión de Derecho Consuetudinário y Pluralismo Legal, 2000.

ITURRALDE, Diego. Tierras y territorios indígenas. Discriminación, inequidad y exclusión. Documento del UNRISD presentado a la Conferencia Mundial Contra el Racismo, Durban, sep., 2001

JIMÉNEZ, Emiliano Borja. Introducción a los Fundamentos del Derecho Penal Indígena. Valencia: Tirant lo Blanch, 2000.

LACERDA, Rosane. Seleção de instrumentos internacionais de direitos humanos relativos a povos indígenas. Curso de Extensão "Direito indigenista para acadêmicos índios de MS”. Brasília-DF, out. 2007. 
LEITÃO, Ana Valéria Nascimento Araújo. Direitos Culturais dos povos Indígenas - Aspectos do seu reconhecimento. In: Juliana Santilli. Os direitos indígenas e a Constituição. Porto Alegre: NDI/Sérgio Antonio Fabris, 1993, p. 225-240.

INSTITUTO SOCIOAMBIENTAL (ISA). Povos Indígenas no Brasil: Guarani Kaiowá. Disponível em: http://pib.socioambiental.org/pt/povo/guarani-kaiowa. Acesso em: 25 jun. 2011.

MAIA, C.; OLIVEIRA DO PRADO, R. C., As Organizações Internacionais e a Proteção dos Povos Indígenas no âmbito do Direito Internacional: O Caso do Brasil. Revista da Faculdade de Direito da Universidade Lusófona do Porto. Ano 1, n. 1, (s. p.) Porto: Editora da Universidade Lusófona do Porto, 2012. (no prelo). ORGANIZAÇÃO DAS NAÇÕES UNIDAS (ONU). Convenção 169 da OIT Sobre Povos Indígenas e Tribais em Países Independentes. In: MAGALHÃES, Edvard Dias (Org.). Legislação Indigenista Brasileira e Normas Correlatas. 3. ed. Brasília: Funai/CGDOC, 2005, 700 p., p. 620-24.

ORGANIZAÇÃO INTERNACIONAL DO TRABALHO (OIT). Peuples Indigènes et Tribaux. Conventions. Disponível em: www.ilo.org/indigenous/Conventions/lang_fr/index.htm. Acesso em: 24 jun. 2011. PACHECO, Rosely Aparecida Stefanes. Direito Indígena: da pluralidade cultural a pluralidade jurídica. Revista Tellus, Núcleos de Estudos e Pesquisas das Populações Indígenas - NEPPI, Campo Grande, a. 6, n. 11, p. 35-38, out. 2006.

. Mobilizações Guarani - Kaiowá Ñandeva e a (Re)construção de Territórios: (1978-2002) Novas Perspectivas para o Direito Indígena. Dissertação, Mestrado em História. UFMS, Dourados, MS, 2004. PACHECO, Rosely Aparecida Stefanes; VERGÍLIO, Ezequias. Por um direito à diferença: a situação jurídico-penal dos presos indígenas kadwéu em Mato Grosso do Sul. In: II Seminário Internacional: Fronteiras Étnico-Culturais E Fronteiras Da Exclusão - Práticas Educativas Num Contexto Intercultural. Campo Grande, UCDB, 2006.

PIOVESAN, Flavia. Apresentação. In: Jayme Benvenuto Lima Júnior. Os direitos humanos econômicos, sociais e culturais. Rio de Janeiro: Renovar, 2001, p. 01-12.

RIBEIRO, Darcy. Os índios e a civilização - A integração das populações indígenas no Brasil Moderno. Rio de Janeiro: Civilização Brasileira, 1970.

SANTOS, Boaventura de Sousa. Pela mão de Alice. O social e o político na pós-modernidade. São Paulo: Cortez, 1995.

SANTOS, Silvio Coelho dos. Povos indígenas e a Constituinte. Florianópolis: Ed. da UFSC/Movimento, 1989. SANTOS FILHO, Roberto Lemos dos. Apontamentos sobre o Direito Indigenista. Curitiba: Juruá, 2005. SILVA, José Afonso da. Curso de Direito Constitucional Positivo. 9. ed. São Paulo: Malheiros, 1993, p. 828. SOUZA FILHO, Carlos Frederico Marés de. O renascer dos povos indígenas para o Direito. Curitiba: Juruá, 2005. STAVEnhaGEN, R. Ethnic Conflicts and the Nacion-State. Nova York: UNRISD, 1996.

. Los derechos culturales y los derechos colectivos en tiempos de Globalización. In: Ingrid Van Beuren;

Oscar Soto Badillo. Derechos Humanos y Globalización alternativa: una perspectiva Iberoamericana. Puebla México: Universidad Ibero Americana, 2004.

WITTGENSTEIN, Ludwig. Tratado Lógico-Filosófico/Investigações Filosóficas. Lisboa: Fundação Calouste Gulbenkian, 1987. 
498 : POPULAÇÃO CARCERÁRIA INDÍGENA E O DIREITO À DIFERENÇA: O CASO DO MUNICÍPIO DE DOURADOS, MS

\section{AneXos}

Listas de PResos indígenas da Penitenciária HaRry Amorin Costa (Dourados, MS)

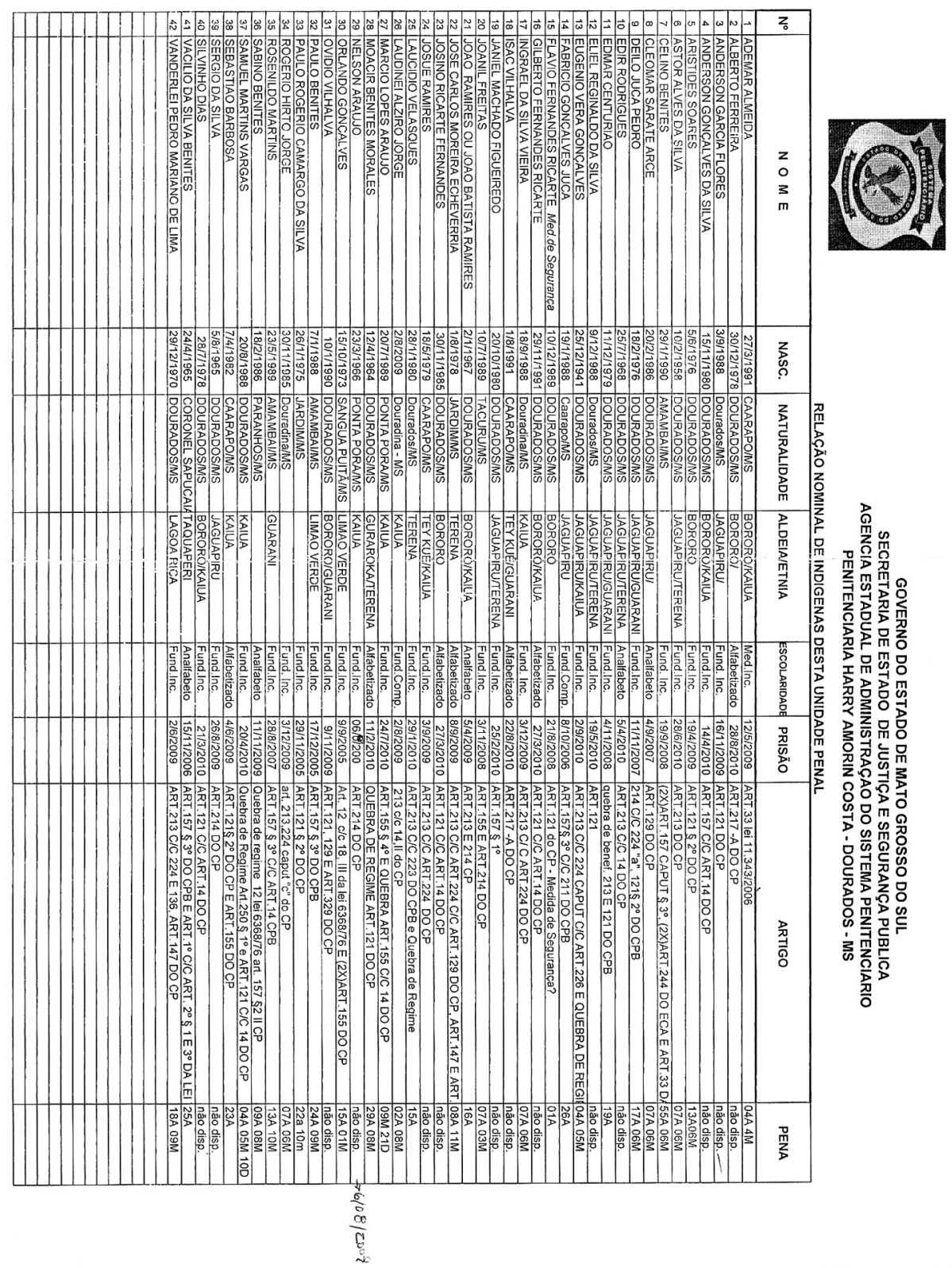




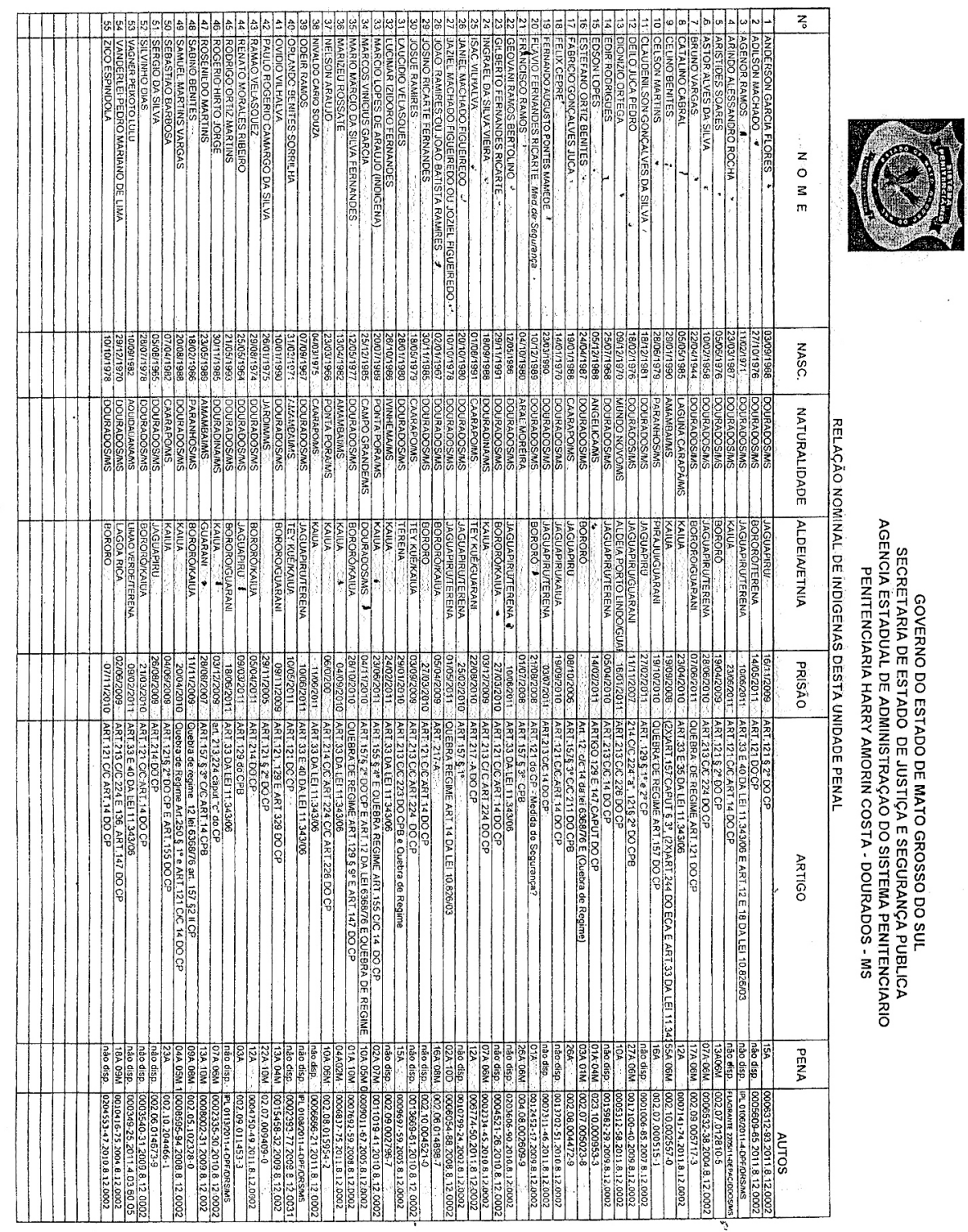


Rodovia Dourados/Itahum, Km 12 Aeroporto - 79825-070 Caixa-Postal 35 Dourados - MS - Brasi roselystefaneslagmail.com

Rodovia Dourados/Itahum, Km 12 Aeroporto - 79825-070 Caixa-Postal 351 Dourados - MS - Brasil pradojusagmail.com Aeroporto - 79825-070 Caixa-Postal 351 Dourados - MS - Brasil kadiweu_ezequiaslahotmail.com

\section{Rosely Aparecida Stefanes Pacheco}

Professora titular da Universidade Estadual de Mato GROSSO DO SUL (UEMS)

ESPECIALISTA EM ANTROPOLOGIA JURÍDICA PELA UNIVERSIDAD DE Chile e É Doutoranda EM DiREITO, LINHA DE PESQuisa DiReITO Socioambiental pela Pontifícia Universidade CATÓlica do PARANÁ (PUC-PR)

Graduada em Direito e HistóRIA, com MESTRAdo EM História, LINHA DE PESQUISA HISTÓRIA INDÍGENA PELA UNIVERSIDADE Federal de Mato Grosso do Sul (UFMS)

\section{Rafael Clemente Oliveira do Prado}

Advogado graduado em CIÊnCIAS JurídicAS PELA FundaC̄ão UniversidAdE dA REgIÃo DE JOINVILLE (UniVILLE)

Mestre (LLM) em Direito Ambiental PELA Universitat

$$
\text { ROVIRA }
$$

I VIRGILI, DE TARRAGONA, ESPANHA

Ex-aluno da Academia de Direito Internacional da HaIA

Pesquisador visitante no Departamento de Direito INTERNACIONAL PÚBLICO E ORganizaÇõES INTERNACIONAIS DA Faculdade de Direito da Universidade de Genebra, Suíça

Ezequias Vergilio Kadwéu

Bacharel em Direito pela Universidade Estadual do Mato GROSSO dO SUL (UEMS)

Pertence a etnia Indígena Kadwéu 